\title{
Astrocytic TDP-43 Pathology in Alexander Disease
}

\author{
Adam K. Walker, ${ }^{1 *}$ Christine M. LaPash Daniels, ${ }^{3 *}$ James E. Goldman, ${ }^{5}$ John Q. Trojanowski, ${ }^{1,2}$ Virginia M.-Y. Lee, ${ }^{1,2}$ \\ and Albee Messing 3,4 \\ ${ }^{1}$ Center for Neurodegenerative Disease Research, Department of Pathology and Laboratory Medicine and 2Institute on Aging, Perelman School of Medicine, \\ University of Pennsylvania, Philadelphia, Pennsylvania 19104, ${ }^{3}$ Waisman Center and ${ }^{4}$ Department of Comparative Biosciences, University of Wisconsin- \\ Madison, Madison, Wisconsin 53705, and 5 Department of Pathology and Cell Biology, Columbia University, New York, New York 10032
}

Alexander disease $(\mathrm{AxD})$ is a rare neurodegenerative disorder characterized pathologically by the presence of eosinophilic inclusions known as Rosenthal fibers (RFs) within astrocytes, and is caused by dominant mutations in the coding region of the gene encoding glial fibrillary acidic protein (GFAP). GFAP is the major astrocytic intermediate filament, and in AxD patient brain tissue GFAP is a major component of RFs. TAR DNA binding protein of $43 \mathrm{kDa}$ (TDP-43) is the major pathological protein in almost all cases of the neurodegenerative disease amyotrophic lateral sclerosis (ALS) and $\sim 50 \%$ of frontotemporal lobar degeneration (FTLD), designated as FTLDTDP. In ALS and FTLD-TDP, TDP-43 becomes insoluble, ubiquitinated, and pathologically phosphorylated and accumulates in cytoplasmic inclusions in both neurons and glia of affected brain and spinal cord regions. Previously, TDP-43 was detected in RFs of human pilocytic astrocytomas; however, involvement of TDP-43 in AxD has not been determined. Here we show that TDP-43 is present in RFs in AxD patient brains, and that insoluble phosphorylated full-length and high molecular weight TDP-43 accumulates in white matter of such brains. Phosphorylated TDP-43 also accumulates in the detergent-insoluble fraction from affected brain regions of Gfap ${ }^{R 236 H /+}$ knock-in mice, which harbor a GFAP mutation homologous to one that causes AxD in humans, and TDP-43 colocalizes with astrocytic RF pathology in $G f a p^{R 236 H /+}$ mice and transgenic mice overexpressing human wild-type GFAP. These findings suggest common pathogenic mechanisms in ALS, FTLD, and AxD, and this is the first report of TDP-43 involvement in a neurological disorder primarily affecting astrocytes.

Key words: Alexander disease; astrocyte; GFAP; mouse models; neurodegeneration; TDP-43

\section{Introduction}

TAR DNA binding protein of $43 \mathrm{kDa}$ (TDP-43) is an essential, highly conserved DNA/RNA binding protein with diverse functions, including regulation of transcription, splicing, and miRNA biogenesis (for review, see Lee et al., 2012). Neurodegenerative TDP-43 proteinopathies, including the vast majority of cases of amyotrophic lateral sclerosis (ALS) and frontotemporal lobar degeneration (FTLD-TDP), are characterized by insoluble TDP-43 pathology (Neumann et al., 2006). Key features of these diseases

Received Jan. 18, 2014; revised March 3, 2014; accepted March 19, 2014.

Author contributions: A.K.W., C.M.L.D., J.E.G., J.Q.T., V.M.Y.L., and A.M. designed research; A.K.W. and C.M.L.D. performed research; J.E.G., J.Q.T., V.M.-Y.L., and A.M. contributed unpublished reagents/analytic tools; A.K.W. and C.M.L.D. analyzed data; A.K.W., C.M.L.D., V.M.-Y.L., and A.M. wrote the paper.

This work was supported by National Institutes of Health (NIH)/National Institute on Aging AG032953, AG10124, AG17586, and AG32953; NIH/National Institute of Neurological Disorders and Stroke NS42803 and NS060120; NIH/ National Institute of Child Health and Human Development (NICHD) HD03352; and the Juanma Fund. A.K.W. holds an Australian National Health and Medical Research Council C.J. Martin Biomedical Early Career Fellowship (1036835). Human tissue was obtained from the NICHD Brain and Tissue Bank for Developmental Disorders at the University of Maryland. We thank Elizabeth Austin, Guanghui Ge, Theresa Schuck, and Melissa Zhou for technical assistance; Linda Kwong for helpful discussion; and James Powers and Michael Brenner for access to human tissue samples.

*A.K.W. and C.M.L.D. contributed equally to this work.

The authors declare no competing financial interests.

Correspondence should be addressed to either of the following: Adam Walker, Center for Neurodegenerative Disease Research, Maloney 3, HUP, 3600 Spruce Street, Philadelphia, PA 19104, E-mail: adwa@upenn.edu; or Albee Messing, Waisman Center, University of Wisconsin, Madison, WI 53705, E-mail: messing@waisman.wisc.edu.

DOI:10.1523/JNEUROSCI.0248-14.2014

Copyright $\odot 2014$ the authors $\quad 0270-6474 / 14 / 346448-11 \$ 15.00 / 0$ are the mislocalization of TDP-43 from the nucleus to the cytoplasm and formation of phosphorylated TDP-43-positive intracellular inclusions (Neumann et al., 2006). TDP-43 pathology is also detected in a variable number of patients with other neurodegenerative diseases, including Alzheimer's, Parkinson's, and Huntington's diseases (Nakashima-Yasuda et al., 2007; Schwab et al., 2008; Uryu et al., 2008), and TDP-43 pathology is a robust correlate of aging-related cognitive impairments (Wilson et al., 2013). Furthermore, TDP-43 was detected in eosinophilic granular bodies and Rosenthal fibers (RFs) in several cases of low-grade pilocytic astrocytoma (Lee et al., 2008). These findings raise the intriguing possibility that TDP-43 may play a role in Alexander disease $(\mathrm{AxD})$, a rare neurodegenerative disease primarily affecting astrocytes, in which RF pathology is the hallmark feature with associated astrogliosis and loss of myelin (Messing et al., 2012).

AxD presents with onset ranging from early infanthood to mid-life, with signs and symptoms including seizures, encephalopathy, and developmental delay in type I patients (typically with a younger onset) and bulbar symptoms and ocular/palatal movement abnormalities with atypical MRI findings in type II patients (typically with an older onset) (Prust et al., 2011; Messing et al., 2012). Over $95 \%$ of cases are caused by mutations in the gene encoding glial fibrillary acidic protein (GFAP), which usually arise de novo but can also be dominantly inherited (Brenner et al., 2001). More than 106 such disease-linked GFAP mutations have been identified (Prust et al., 2011). The amino acid most 
Table 1. Clinical and genetic details of patient samples analyzed by IB and IHC

\begin{tabular}{|c|c|c|c|c|c|c|}
\hline Case & Disease & Age at onset & Age at death (years) & GFAP mutation & Sex & $\mathrm{IHC}$ or IB \\
\hline AxD 1 & Infantile-onset/type I & 3 months & 1 & $\mathrm{R} 239 \mathrm{H}$ & M & IB and IHC (frontal/temporal WM) \\
\hline $\operatorname{AxD} 2$ & Infantile-onset/type I & 13 months & 6 & $\mathrm{R} 239 \mathrm{C}$ & M & IB and IHC (frontal WM) \\
\hline AxD 3 & Infantile-onset/type I & 3 months & 14 & $\mathrm{R} 79 \mathrm{C}$ & M & $\mathrm{IB}$ \\
\hline AxD 4 & Juvenile-onset/type II & 3.5 years & 22 & L359V & M & IB \\
\hline $\operatorname{AxD} 5$ & Adult-onset/type II & 37 years & 42 & D417A & $\mathrm{F}$ & IB and IHC (frontal WM) \\
\hline AxD 6 & Adult-onset/type II & 25 years & 50 & S247P & $\mathrm{F}$ & IB and IHC (frontal WM) \\
\hline AxD 7 & Infantile-onset/type I & 1 month & 4 months & ND & M & IHC (cortex, cerebellum, brainstem, spinal cord) \\
\hline AxD 8 & Juvenile-onset/type II & 1 year & 8 & R416W & M & IHC (hippocampus, cortex, medulla) \\
\hline AxD 9 & Adult-onset/type II & 14 years & 39 & Splice site & $\mathrm{F}$ & $\begin{array}{l}\text { IHC (frontal, temporal, occipital, hippocampus, } \\
\text { cerebellum, medulla, thoracic spinal cord) }\end{array}$ \\
\hline Control 1 & Arteriosclerotic cardiovascular disease & - & 50 & - & $\mathrm{F}$ & IB \\
\hline Control 2 & Arteriosclerotic cardiovascular disease & - & 38 & - & $\mathrm{F}$ & IB \\
\hline Control 3 & Cardiac arrhythmia & - & 14 & - & M & IB \\
\hline Control 4 & Normal & - & 42 & - & M & IB \\
\hline Control 5 & Normal (metastatic adenocarcinoma) & - & 51 & - & $\mathrm{F}$ & $\mathrm{IB}$ and IHC \\
\hline Control 6 & Normal (liver failure) & - & 46 & - & $\mathrm{F}$ & $\mathrm{IB}$ \\
\hline AD 1 & Alzheimer's & - & 51 & - & M & IB \\
\hline$A D 2$ & Alzheimer's/Down's & - & 47 & - & $\mathrm{F}$ & IB \\
\hline AD 3 & Alzheimer's & - & 47 & - & $\mathrm{F}$ & IB \\
\hline FTLD 1 & FTLD-C9 & 35 years & 41 & - & M & IB \\
\hline FTLD 2 & FTLD-TDP & - & 65 & - & M & $\mathrm{IHC}$ \\
\hline
\end{tabular}

AD, Alzheimer's disease; IB, immunoblotting; IHC, immunohistochemistry; ND, not determined.

commonly mutated is R239, accounting for $\sim 20 \%$ of all GFAP mutations (Prust et al., 2011), and knock-in mutation of the mouse equivalent $G f a p^{R 236 H}$ causes pathological features of $\mathrm{AxD}$, including increased GFAP levels, formation of eosinophilic RFlike pathology, and activation of multiple stress pathways (Hagemann et al., 2006, 2013). Similarly, overexpression of wild-type human GFAP in mice causes fatal encephalopathy with AxD-like pathology (Messing et al., 1998).

Given the broad involvement of TDP-43 in neurodegenerative diseases, and the finding of colocalization of TDP-43 with RFs in pilocytic astrocytoma, we hypothesized that TDP-43 is also involved in AxD. Here we show that full-length TDP-43 is phosphorylated, colocalizes with RFs, and becomes insoluble in AxD patient CNS tissues. The phosphorylation of TDP-43 correlates with age of disease onset and with the level of GFAP pathology, suggesting an active involvement of TDP-43 in disease pathogenesis. TDP-43 also colocalizes with GFAP in an agedependent manner in Gfap $\mathrm{p}^{R 236 H /+}$ mouse CNS tissues, and TDP-43 similarly colocalizes with RF-like pathology in wild-type GFAP overexpressing mice. This is the first report of the involvement of TDP-43 in a degenerative disease primarily affecting astrocytes, and broadens our understanding of TDP-43 pathology in neurodegenerative diseases to include TDP-43 astrocytopathies. Gfap ${ }^{R 236 H /+}$ and GFAP overexpressing mice represent unique models in which to study TDP-43 pathology without direct manipulation of TDP-43 expression levels.

\section{Materials and Methods}

Human patient samples. Clinical and genetic details of human CNS samples are presented in Table 1. Some human CNS tissues were obtained from the NICHD Brain and Tissue Bank for Developmental Disorders at the University of Maryland, Baltimore, MD (supported by NIH Contract \#HHSN275200900011C, Ref. No. N01-HD-9-001).

Preparation of human brain lysates. Frontal or temporal white matter (WM) samples (50-100 mg) were thawed on ice and mechanically homogenized with $5 \times$ volume per weight in high-salt (HS) buffer $(50 \mathrm{~mm}$ Tris, $750 \mathrm{~mm} \mathrm{NaCl}, 10 \mathrm{~mm} \mathrm{NaF}$, and $5 \mathrm{~mm}$ EDTA, pH 7.4). All buffers were supplemented with $1 \mathrm{~mm}$ PMSF and phosphatase and protease inhibitor cocktails (Sigma). Samples were centrifuged at $100,000 \times g$ for $30 \mathrm{~min}$ at $4^{\circ} \mathrm{C}$ and the supernatant taken as the HS-soluble fraction.
Pellets were re-extracted with HS buffer and centrifuged at 100,000 $\times g$ for $30 \mathrm{~min}$ at $4^{\circ} \mathrm{C}$. This supernatant was discarded, and the pellet extracted by homogenization with $5 \times$ volume per original weight in HS buffer with $1 \%$ Triton X-100. Samples were centrifuged at 100,000 $\times g$ for $30 \mathrm{~min}$ at $4^{\circ} \mathrm{C}$ and the supernatant was taken as the HS-Triton X-100soluble fraction. Pellets were extracted by homogenization with $5 \times$ volume per original weight in HS buffer with $1 \%$ Triton X-100 and $30 \%$ sucrose and centrifuged at $100,000 \times g$ for $30 \mathrm{~min}$ at $4^{\circ} \mathrm{C}$. This supernatant, along with suspended myelin, was discarded, and the pellet was sonicated with $5 \times$ volume per original weight in HS buffer with $1 \%$ Sarkosyl. Samples were incubated at room temperature with agitation for $30 \mathrm{~min}$, and then centrifuged at $100,000 \times g$ for $30 \mathrm{~min}$ at $22^{\circ} \mathrm{C}$ and the supernatant taken as the Sarkosyl-soluble fraction. Pellets were extracted by sonication directly in $1 \times$ volume per original weight of SDS sample buffer ( $0.05 \%$ bromophenol blue, 0.1 м DTT, $10 \%$ glycerol, $2 \%$ SDS, and $50 \mathrm{~mm}$ Tris, $\mathrm{pH}$ 6.8) and then heated at $95^{\circ} \mathrm{C}$ for 5 min before immunoblotting.

GFAP mutant and transgenic mice. Knock-in mice heterozygous for the Gfap ${ }^{R 236 H /+}$ point mutation (Hagemann et al., 2006) and transgenic mice overexpressing wild-type human genomic GFAP (GFAP ${ }^{T g}$; Messing et al., 1998) were generated as previously described and maintained in the FVB/N background. Three- and 10-week-old male mice were used for experiments. All studies were approved by the Animal Care and Use Committee for the Graduate School at the University of Wisconsin-Madison.

Mouse tissue collection. Mice were killed by $\mathrm{CO}_{2}$ inhalation, and brains were removed and dissected in ice-cold PBS. Olfactory bulb, hippocampus, and corpus callosum were immediately frozen in liquid nitrogen and stored at $-80^{\circ} \mathrm{C}$.

Preparation of mouse brain sections. For frozen sections, mice were perfused intracardially with room temperature PBS followed by fresh $4 \%$ paraformaldehyde in $0.1 \mathrm{M}$ phosphate buffer, $\mathrm{pH}$ 7.4. Brains were postfixed overnight at $4^{\circ} \mathrm{C}$, cryoprotected in graded concentrations of sucrose in PBS ( $\sim 5 \mathrm{~h}$ at $10 \%, \sim 20 \mathrm{~h}$ at $20 \%,>48 \mathrm{~h}$ at $30 \%)$, embedded in Tissue-Tek O.C.T. compound (Sakura Finetek), frozen in a dry ice/ethanol bath, and sectioned at $16 \mu \mathrm{m}$ on a cryostat. For paraffin sections, mice were killed by $\mathrm{CO}_{2}$ inhalation, and the brains immersion fixed in $10 \%$ formalin overnight at room temperature, rinsed in Tris-buffered saline, $\mathrm{pH} 7.4$ (50 mm Tris and $150 \mathrm{~mm} \mathrm{NaCl}$ ), embedded in paraffin, and sectioned at $6 \mu \mathrm{m}$.

Immunofluorescence and immunohistochemistry. For immunofluorescence on frozen sections, sections were microwaved in $10 \mathrm{~mm}$ citrate buffer, pH 6.0, for 8 min; blocked in 3\% donkey serum (DS) in PBS with 
$0.25 \%$ Triton X-100; incubated with a mouse anti-GFAP monoclonal antibody (MAb; 1:1000; clone GA5; Millipore MAB3402) and a rabbit anti-TDP-43 polyclonal antibody (PAb; 1:100; Protein Tech Group 12892-1-AP) in blocking solution; followed by a donkey anti-mouse Alexa 488-labeled PAb and a donkey anti-rabbit Alexa 546-labeled PAb (1:1000; Invitrogen) in 3\% DS in PBS. Slides were coverslipped using ProLong Gold mounting media with DAPI (Invitrogen) and imaged on a Nikon $\mathrm{C} 1$ confocal microscope. Images are maximum intensity projections of $7 \mu \mathrm{m} z$-stacks ( $7 \times 1 \mu \mathrm{m} z$-sections per stack). For immunohistochemistry (IHC) on frozen sections, slides were microwaved in $10 \mathrm{~mm}$ citrate buffer, $\mathrm{pH}$ 6.0, for $8 \mathrm{~min}$; incubated in 3\% hydrogen peroxide and $90 \%$ methanol; blocked in 3\% normal goat serum with $0.25 \%$ Triton X-100; and incubated with a rabbit anti-TDP-43 PAb (1:5000; Protein Tech Group 12892-1-AP) in blocking solution, followed by biotinylated goat anti-rabbit PAb. For IHC on paraffin sections, sections were deparaffinized in xylenes and rehydrated in descending series of ethanol. Endogenous peroxidases were blocked with $5 \%$ hydrogen peroxide in methanol, sections were microwaved in $1 \%$ antigen unmasking solution (Vector Laboratories) at $95^{\circ} \mathrm{C}$ for $15 \mathrm{~min}$, blocked in $2 \% \mathrm{FBS}$ in $0.1 \mathrm{M}$ Tris buffer, and incubated with a rabbit anti-TDP-43 PAb (1:5000; Protein Tech Group 12892-1-AP), a rabbit anti-TDP-43 PAb (1:6000; Protein Tech Group 10782-2-AP), a rabbit anti-TDP-43 C terminus-specific PAb [1:5000; CNDR C1039 (Igaz et al., 2008)], a rat anti-phospho-S409/410TDP-43 MAb [1:200; clone 1D3, CNDR (Neumann et al., 2009)], a rabbit anti-phospho-S403/404 PAb (1:5000; Cosmo Bio TIP-PTD-P05), a mouse anti-ubiquitin MAb (1:10,000; clone Ubi-1; Millipore MAB1510), a rabbit anti-TDP-43 N terminus-specific PAb [1:5000, CNDR N1065 (Igaz et al., 2008)], a rabbit anti-GFAP PAb (1:5000; Dako z0334), or a rat anti-GFAP MAb [1:5000; clone 2.2B10, CNDR (Lee et al., 1984)] in blocking solution at $4^{\circ} \mathrm{C}$ for $16-18 \mathrm{~h}$. Labeling was detected using the Vectastain $\mathrm{ABC}$ kit followed by incubation with $0.05 \%$ 3,3'-diaminobenzidine tetrahydrochloride hydrate (Sigma D5637) with $0.003 \%$ hydrogen peroxide in $0.1 \mathrm{M}$ phosphate buffer, $\mathrm{pH} 7.4$, and sections were counterstained with hematoxylin. Slides were coverslipped with VectaMount AQ aqueous mounting medium (Vector Laboratories) or Cytoseal 60 toluene mounting medium (Thermo Scientific). Images were acquired using a Nikon Eclipse Ni inverted microscope with DS-Fi2 camera, and RFs were detected as dense structures visible by hematoxylin or eosin counterstain.

Preparation of mouse brain lysates. Mouse brain samples were thawed on ice and sonicated with $5 \times$ volume per weight of radioimmunoprecipitation (RIPA) buffer (50 mm Tris, $150 \mathrm{~mm} \mathrm{NaCl}, 1 \% \mathrm{NP}-40,5 \mathrm{~mm}$ EDTA, $0.5 \%$ sodium deoxycholate, and $0.1 \%$ SDS, pH 8.0) containing 1 mM PMSF and phosphatase and protease inhibitor cocktails (Sigma). Samples were centrifuged at $100,000 \times g$ for $30 \mathrm{~min}$ at $4^{\circ} \mathrm{C}$ and the supernatant taken as the RIPA-soluble fraction. Pellets were sonicated with RIPA buffer to ensure removal of all soluble proteins, and centrifuged at $100,000 \times g$ for $30 \mathrm{~min}$ at $4^{\circ} \mathrm{C}$. The insoluble pellets were sonicated with $2 \times$ volume per original sample weight in urea buffer $(7 \mathrm{M}$ urea, $2 \mathrm{~m}$ thiourea, $4 \%$ CHAPS, and $30 \mathrm{~mm}$ Tris, $\mathrm{pH}$ 8.5) and centrifuged at $100,000 \times g$ for $30 \mathrm{~min}$ at $22^{\circ} \mathrm{C}$. The supernatant was taken as the ureasoluble fraction. Protein concentrations of the RIPA-soluble fraction were determined using the bicinchoninic acid protein assay (Pierce).

Enzymatic dephosphorylation. Mouse CNS urea-soluble protein fractions were dialyzed using $3.5 \mathrm{kDa}$ MW cutoff dialysis membrane (Spectrum Labs) into $50 \mathrm{~mm}$ Tris, $\mathrm{pH} 8.0$, with $0.5 \mathrm{~mm}$ PMSF for $16 \mathrm{~h}$ at $4^{\circ} \mathrm{C}$. Samples were supplemented with reaction buffer and incubated with $\lambda$-phosphatase (New England BioLabs) for $1 \mathrm{~h}$ at $30^{\circ} \mathrm{C}$ according to the manufacturer's protocol, before immunoblotting. Control reactions were processed in parallel without addition of $\lambda$-phosphatase.

Immunoblotting. Thirty micrograms of RIPA-soluble protein and an equivalent amount of the corresponding urea-soluble fraction were analyzed by immunoblotting using 10\% SDS-PAGE and nitrocellulose membranes (Bio-Rad). Antibodies for immunoblotting were as follows: rabbit anti-TDP-43 C terminus PAb (1:10,000; CNDR C1039), rat antiphospho-S409/410-TDP-43 MAb (1:100; clone 1D3, CNDR), rabbit anti-TDP-43 PAb (1:1500; ProteinTech Group 12892-1-AP), rabbit antiGFAP PAb (1:5000; Dako z0334), mouse anti-ubiquitin MAb ([1:1000; clone 1B4, CNDR (Neumann et al., 2006)], and mouse anti-GAPDH
MAb (1:10,000; clone 6C5; Advanced Immunochemical 2-RGM2). Blots were incubated with secondary antibodies IRDye 680/800- conjugated goat anti-mouse or anti-rabbit IgG (Li-Cor) or IRDye 800 -conjugated goat anti-rat IgG (Rockland) PAbs and developed using a Li-Cor Odyssey imaging system. Optical densities of immunobands were quantified using Li-Cor Image Studio version 2.0 software.

\section{Results}

\section{Phosphorylated TDP-43 in RFs of AxD patients}

Previously, rare TDP-43 immunoreactivity was detected at the periphery of RFs in several cases of pilocytic astrocytoma (Lee et al., 2008). Given that RFs are the hallmark neuropathology in $\mathrm{AxD}$, we hypothesized that TDP-43 could also be present in the RF pathology of AxD patients' brains and spinal cords. Hematoxylin and eosin (H\&E) staining was initially performed to confirm the presence of RF pathology in affected brain and spinal cord regions of seven confirmed cases of $\mathrm{AxD}$ including those with infantile-onset type I, juvenile-onset type II, and adult-onset type II disease (Table 1). We analyzed frontal WM from four AxD cases, and additional regions, including hippocampus, cerebral cortex, cerebellum, medulla, brainstem, and spinal cord, from three additional $\mathrm{AxD}$ cases. Histological analyses showed that large, dense eosinophilic RFs, which were immunoreactive at their periphery for a GFAP antibody, were readily detectable in affected regions (Fig. $1 A, B$ ). IHC using a panel of TDP-43 antibodies revealed peripheral immunoreactivity of RFs for phosphorylated (pS409/410) and total TDP-43 in two of the four cases in which a single frontal WM sample was available (AxD1 and AxD5; Fig. 1C). Immunostaining of GFAP and normal nuclear TDP-43 was negative in multiple runs in the two remaining cases with only one sample available (AxD2 and AxD6), presumably due to tissue processing or very long fixation times.

While normal nuclear TDP-43 was detected in adjacent unaffected gray matter (Fig. 1D), up to $\sim 50 \%$ of RFs in WM of numerous regions, including occipital and temporal WM, medulla, and thoracic spinal cord, were detected using antibodies specific for pS409/410 and N-terminal or C-terminal regions of TDP-43 in two of the three cases in which several brain regions were available for analysis (AxD8 and AxD9; Fig. 1E-G). Tissue from the remaining case of a 4-month-old boy, $\mathrm{AxD} 7$, did not reveal TDP-43-positive RFs. Overall, TDP-43 was detected at the periphery of RFs in four of the seven cases analyzed. Whether the lack of detection of TDP-43 pathology in the three remaining cases was due to a lack of TDP-43 pathology or tissue processing/ degradation remains uncertain. In TDP-43-positive cases, IHC staining was detected by antibodies directed against both $\mathrm{N}$-terminal and C-terminal regions of TDP-43 (Fig. 1D-F,H), suggesting incorporation of phosphorylated full-length TDP-43 into the RFs. Notably, the pattern of peripheral RF staining for TDP-43 was similar to that seen for GFAP, although TDP-43 immunoreactivity was more often detected at the periphery of smaller thread-like RFs, rather than in larger globular RFs. No such immunostaining of TDP-43 was observed in human control cases or those with a variety of diverse neurodegenerative diseases (data not shown; Neumann et al., 2006). Furthermore, the pattern of WM TDP-43 pathology in AxD was distinct from the cytoplasmic inclusions and dystrophic neurites seen in gray matter of FTLD-TDP patient tissue, and TDP-43-positive inclusions were not observed in $\mathrm{AxD}$ patient neurons (Fig. $1 H$ ).

\section{Insoluble TDP-43 is pathologically phosphorylated in $\mathrm{AxD}$ patient WM}

The presence of pS409/410 TDP-43 immunoreactivity in RFs suggested that TDP-43 may be abnormal since phosphorylation 

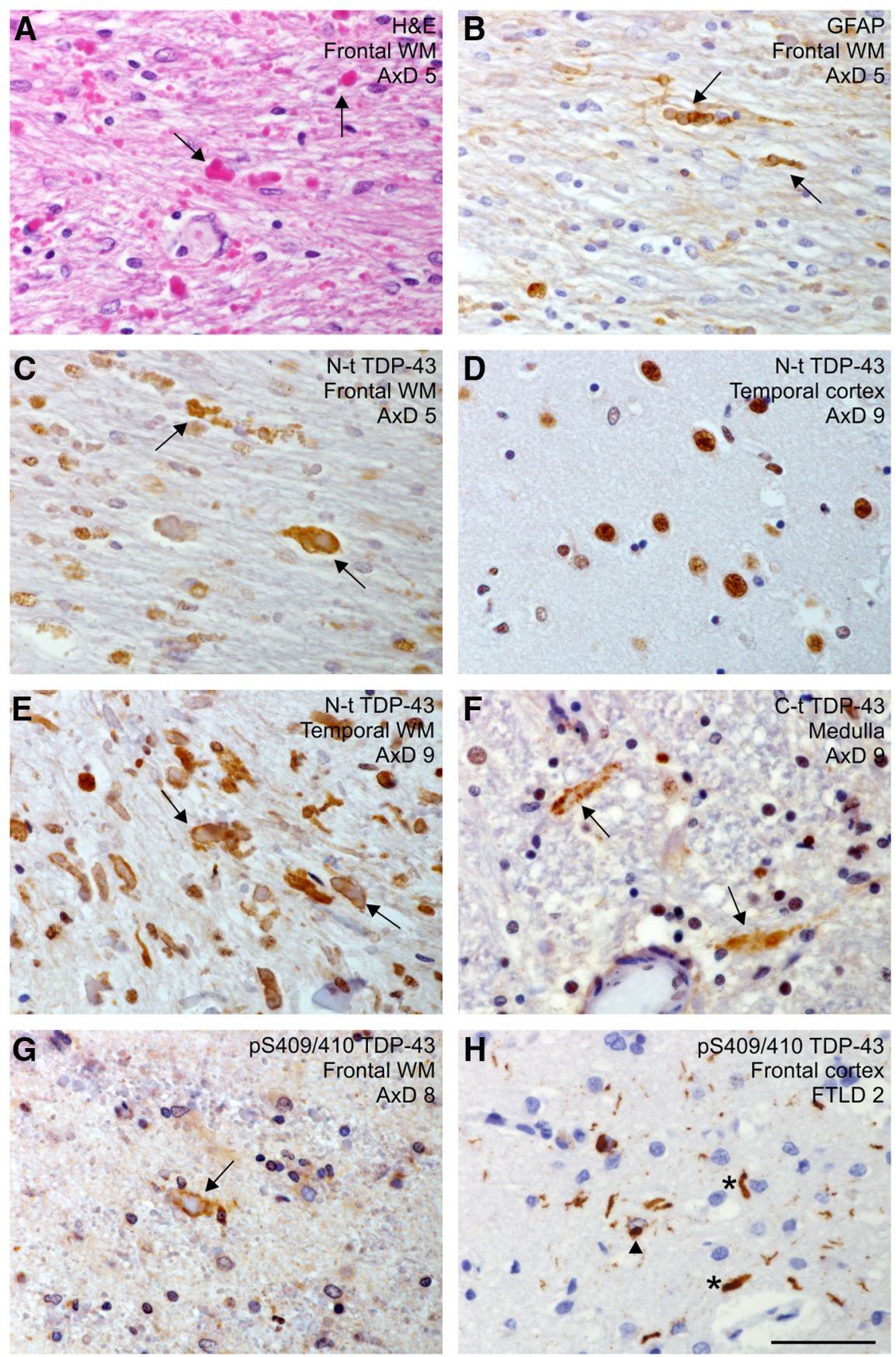

Figure 1. TDP-43 is detected in RF pathology in AxD patients. $A$, AxD patient tissue shows eosinophilic RFs (arrows) in H\&Estained affected frontal WM. B, RFs (arrows) are immunoreactive at the periphery for GFAP. IHC for N-terminal (N-t) TDP-43 (antibody N1065) in frontal WM (C) revealed a similar peripheral RF pattern. Normal nuclear TDP-43 was detected in neighboring temporal cortex (D), compared with RF pathology in temporal WM (E). C-terminal (C-t) TDP-43 (antibody C1039) in medulla $(\boldsymbol{F})$ and DS409/410 TDP-43 (antibody 1D3) in frontal WM (G) reveal peripheral immunoreactivity of RFs (arrows) in AxD patients, which is distinct from cytoplasmic inclusions (arrowhead) and dystrophic neurites (asterisk) in frontal cortex of FTLD-TDP patient tissue $(\boldsymbol{H})$. Magnification is consistent between panels. Scale bar: (in $\boldsymbol{H}) \boldsymbol{A}-\boldsymbol{H}, 50 \mu \mathrm{m}$.

at these sites was previously detected only in pathological conditions (Neumann et al., 2009). Moreover, the presence of aberrantly phosphorylated TDP-43 is usually accompanied by a shift in solubility and molecular weight. Therefore, pathological TDP-43 could be rendered insoluble in AxD, similar to the findings of altered solubility in ALS and FTLD patient brain tissue (Neumann et al., 2006). To demonstrate the presence of insoluble pS409/410 TDP-43, human brain samples were sequentially extracted with buffers of increasing extraction strength and analyzed for levels of total as well as phosphorylated TDP-43 in the Sarkosylinsoluble but SDS-soluble fractions. Temporal or frontal WM from six AxD patients was analyzed, along with FTLDTDP, Alzheimer's disease lacking TDP-43 pathology, and non-neurological frontal WM controls. Although levels of total TDP-43 were not consistently altered in AxD patients, a dramatic increase in pS409/410-TDP-43 was detected in the three type I AxD cases, representing the youngest of the six patients analyzed (AxD1, AxD2, and AxD3; Fig. 2A,B). The youngest type II AxD case (AxD4) also had detectable levels of pS409/410-TDP43, which were not detected in the two oldest $\mathrm{AxD}$ cases (AxD5 and AxD6) or in any control or Alzheimer's disease tissues (Fig. 2A,B; data not shown). Bands of $\sim 45 \mathrm{kDa}$, corresponding in size to those in the FTLD-positive control, as well as a high molecular weight TDP-43 protein smear, were detected. Furthermore, although $20-25 \mathrm{kDa}$ C-terminal TDP-43 fragments were readily detected in FTLD control tissue, these TDP-43 fragments were either absent or present at only very low levels even in the youngest, most severely affected $A x D$ cases (Fig. $2 C, D$ ). These findings suggest differences in the post-translational processing of TDP-43 in AxD compared with other TDP-43 proteinopathies, the latter having cleavage of the protein to generate $\mathrm{C}$-terminal fragments as a prominent feature (Neumann et al., 2006). Interestingly, the levels of phosphorylated TDP-43 in AxD patients correlated with the detection of increased accumulation of insoluble GFAP and ubiquitin (Fig. 2E, F), suggesting increased TDP-43 pathology in the most severely affected tissues.

\section{Mislocalized and pathologically phosphorylated TDP-43 pathology occurs in mouse models of $\mathrm{AxD}$ and increases with age}

We next determined whether TDP-43 pathology also occurs in mouse models of AxD. Gfap ${ }^{R 236 H /+}$ mice have a point mutation in the Gfap gene that is homologous to the common $\mathrm{R} 239 \mathrm{H}$ mutation in human $\mathrm{AxD}$ patients, and these mice exhibit key features of human $\mathrm{AxD}$, including widespread RFs, astrogliosis, increased GFAP levels, activation of stress pathways, cognitive deficits, and susceptibility to seizures (Hagemann et al., 2006, 2013). An antibody directed to the C-terminal portion of TDP-43 (amino acids 260-414, antibody PTG 12892) detected abnormally localized TDP-43 in Gfap ${ }^{R 236 H /+}$ mice and the pathological TDP-43 labeling corresponded to brain regions affected by disease. In WT control littermates, TDP-43 was mostly confined to nuclei throughout the brain at both 3 and 10 weeks of age (Fig. 
$3 A, C)$. In contrast, TDP-43 was found in the cytoplasm of some cells of $G f a p^{R 236 H /+}$ mice by 3 weeks of age, especially in regions where RFs were detected, such as the pial surface of piriform cortex (Fig. 3B), the lacunosum moleculare layer of hippocampus, olfactory bulb, and corpus callosum. Just as GFAP expression levels and RF-like pathology increase with age, pathological TDP-43 labeling similarly increased between 3 and 10 weeks of age (Fig. 3, compare B,D). More cells exhibited cytoplasmic TDP-43 labeling by 10 weeks, and labeling within individual cells appeared to extend further away from the nucleus and cell body into more distal cell processes (Fig. $3 B, D$ ).

In a pattern similar to the increased GFAP expression in hypertrophic astrocytes and RF pathology, pathological TDP-43 labeling extended into the stratum radiatum, pyramidal layer, stratum oriens, and external capsule of the hippocampus in 10-week-old mice, detected with C-terminal TDP-43 antibody (Fig. 3F), pS409/410 (Fig. 3H), and pS403/404 TDP-43 (Fig. 3J). Diffuse TDP-43 immunolabeling in $G f a p^{R 236 H /+}$ cells was visible throughout the cytoplasm of the cell body and proximal processes and was more intense in cytoplasm compared with the nucleus, compared with the nuclear TDP-43 immunolabeling in WT littermate control mice (Fig. $3 E, G, I$ ). Punctate TDP-43 immunolabeling was visible in the cytoplasm of some Gfap ${ }^{R 236 H /+}$ cells (Fig. $3 F, H$, J insets). The TDP-43 pathology displayed a similar pattern of expression to GFAP (Fig. $3 L$ ) and ubiquitin (Fig. 3N). Moreover, pS409/410 also detected astrocytic pathology in olfactory bulb (Fig. 3O) and pial surface of the cortex (Fig. 3P).

Finally, transgenic mice overexpressing human GFAP (GFAP $P^{T g}$ mice) have a more severe phenotype than the Gfap ${ }^{R 236 H /+}$ mice, including more RFs and higher levels of GFAP (Messing et al., 1998; Hagemann et al., 2006). TDP-43 labeling was similarly detected in hippocampal astrocytic pathology with antibodies against pS409/410, pS403/404, and total TDP-43 (Fig. 3Q-S). As with $G f a p^{R 236 H /+}$ mice, GFAP $P^{T g}$ mice also showed phosphorylated TDP-43 pathology in some astrocytic processes, including in the pial surface of the cortex (Fig. $3 T$ ).

Other TDP-43 antibodies, such as C1039 (rabbit polyclonal, amino acids 394-414) and N1065 (rabbit polyclonal, amino acids 1-260), detected nuclear TDP-43 labeling in both WT and Gfap ${ }^{R 236 H /+}$ mice, but did not detect significant amounts of cytoplasmic TDP-43 labeling in Gfap $p^{R 236 H /+}$ mice despite detecting pathology in human FTLD-TDP-positive control tissue (data not shown). In contrast, the N1065 antibody, but not the C1039 antibody, detected a small number of RF-like structures in the GFAP ${ }^{T g}$ mice, although the pattern of staining was not as extensive as with the PTG 12892, pS403/404, or pS409/410 antibodies (data not shown). Notably, both the C1039 and N1065 antibodies did detect RFs in AxD patient tissue (Fig. 1), indicating some differ- ences in the TDP-43 pathology found in Gfap $p^{R 236 H /+}$ and $G F A P^{T g}$ mice compared with $\mathrm{AxD}$ patients. The RF-like pathology found in these mouse models at a relatively young age (3-10 weeks) may not be as "mature" as RFs found in AxD patients, and pathological TDP-43 may display different abnormal epitopes compared with human $\mathrm{AxD}$ tissues. Additionally, another C-terminal region-specific TDP-43 antibody, PTG 10782, failed to detect pathology in both AxD patient tissue and in $G f a p^{R 236 H /+}$ and $G F A P^{T g}$ mice (data not shown). Conformational changes in the pathological TDP-43 in RF due to potential interaction with GFAP may cause selective masking of the epitopes detected by some of the TDP-43 antibodies used here.

\section{Cytoplasmic TDP-43 colocalizes with GFAP in AxD mice}

We next tested whether mislocalization of TDP-43 occurred specifically in astrocytes using double-label immunofluorescence with mouse anti-GFAP and rabbit anti-TDP-43 antibodies in 10-week-old mice. In littermate control WT mice, TDP-43 was mostly confined to nuclei in olfactory bulb (Fig. $4 A$ ) and hippocampus (Fig. 4G). However, in Gfap ${ }^{R 236 H /+}$ mice, TDP-43 was localized to nuclei as well as GFAP-positive cell bodies and proximal processes in olfactory bulb (Fig. $4 D-F$, arrows), hippocampus (Fig. $4 J-L$, arrows), and piri- 

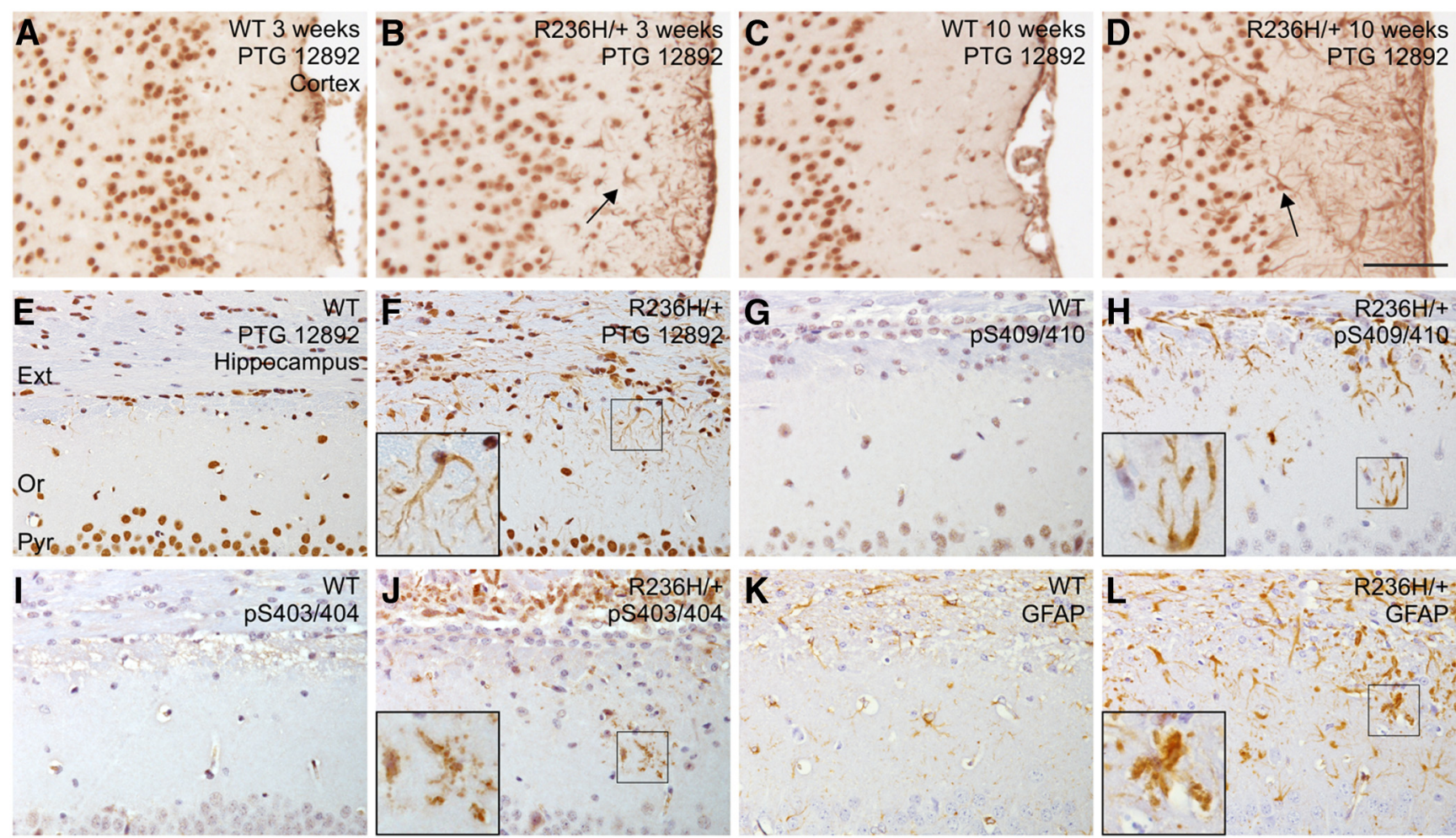

$\mathrm{Pyr}_{0.0}: 0 \%$
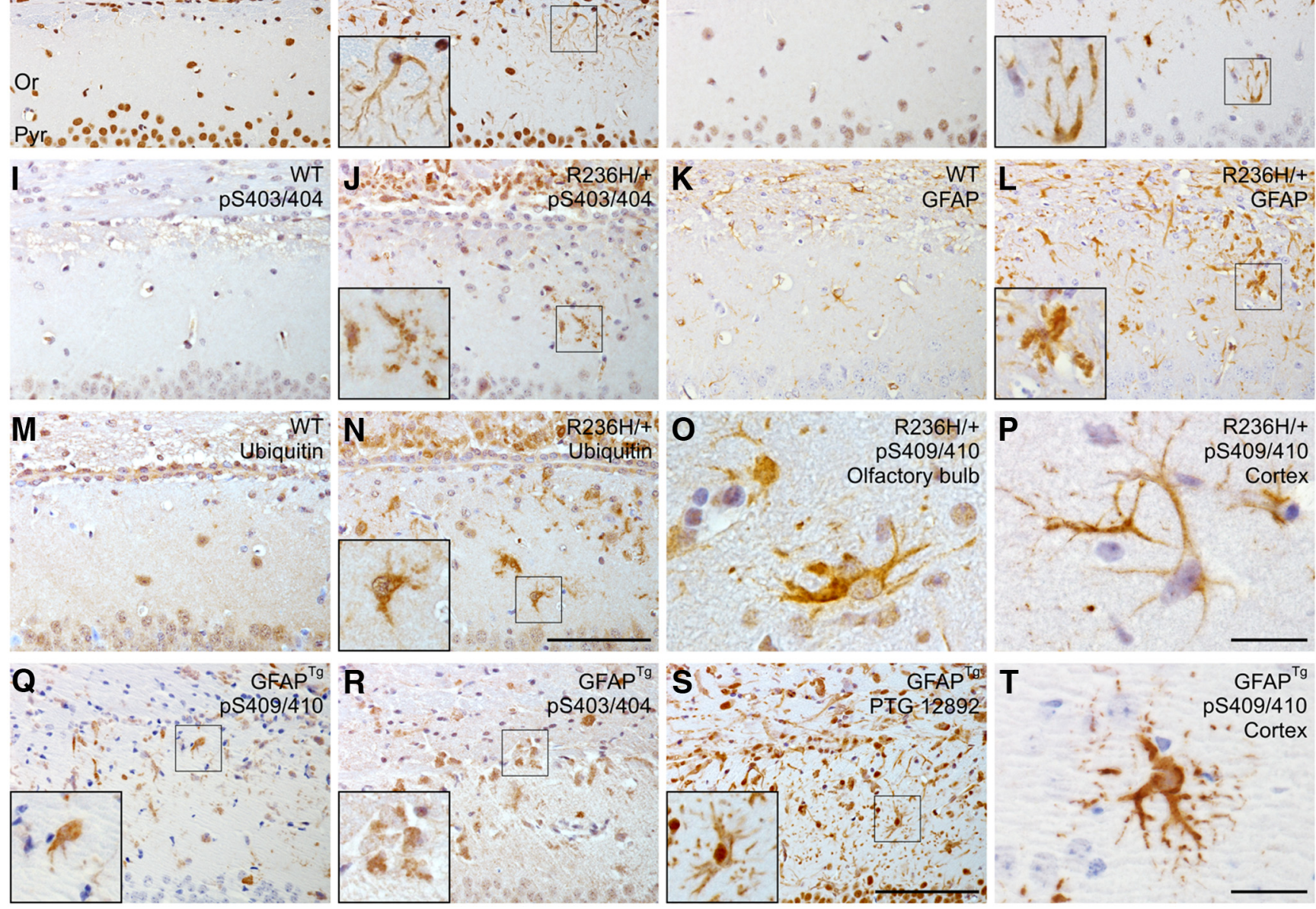

Figure 3. Mislocalization of TDP-43 occurs throughout the brains of $G F a p^{R 236 H /+}$ and GFAPTg mice and increases with age. A-D, TDP-43 immunolabeling (antibody PTG 12892) in coronal sections of piriform cortex (representative of $n=3$ mice per genotype). In WT cortex, TDP-43 immunoreactivity is confined to nuclei at 3 weeks $(\boldsymbol{A})$ and 10 weeks (C). In Gfap ${ }^{R 236 H /+}$ cortex, TDP-43 immunoreactivity is found in the cytoplasm of many cells (arrows) near the pial surface of the brain at 3 weeks $(\boldsymbol{B})$ and is further increased at 10 weeks $(\boldsymbol{D})$. $\boldsymbol{E}-\boldsymbol{N}$, Immunolabeling of mouse hippocampus at 10 weeks (representative of $n>3$ mice per genotype). In WT hippocampus, TDP-43 immunolabeling (antibody PTG 12892) is confined to nuclei (E), but in Gfap ${ }^{R 236 H /+}$ hippocampus, TDP-43 is detected in the cytoplasm of astrocytes $(\boldsymbol{F})$. Immunolabeling for pS409/410 and pS403/404 TDP-43 shows low level of background nuclear staining in WT (G, $I$ ) but dramatically increased cytoplasmic labeling in $\mathrm{Gfap}^{R 236 \mathrm{H} /+}$ mice $(\boldsymbol{H}, \boldsymbol{J})$. Astrogliosis and RF pathology are detected using anti-GFAP antibody in $\mathrm{Gfap}^{\mathrm{R} 236 \mathrm{H} /+}$ mice compared with WT mice $(\boldsymbol{K}, \boldsymbol{L})$. The cytoplasmic pathology in $G \mathrm{fap}^{R 236 \mathrm{H} /+}$ mice also contains ubiquitin not detected in WT mice $(\boldsymbol{M}, \boldsymbol{N})$. pS409/410 TDP-43 pathology is similarly detected in olfactory bulb $(\mathbf{0})$ and pial surface of the cortex $(\boldsymbol{P})$ in Gfap ${ }^{R 236 H /+}$ mice. In GFAPTg mice, astrocytic pathology is also detected by pS409/410, pS403/404 TDP-43, and total TDP-43 antibodies in hippocampus and cortex $(\mathbf{Q}-\boldsymbol{T})$. Boxes indicate magnified insets. Scale bars: $\boldsymbol{A}-\boldsymbol{D}, 100 \mu \mathrm{m} ; \boldsymbol{E}-\boldsymbol{N}, 100 \mu \mathrm{m} ; \mathbf{0}, \boldsymbol{P}, 25 \mu \mathrm{m} ; \mathbf{Q}-\boldsymbol{S}, 100 \mu \mathrm{m} ; \boldsymbol{T}, 25 \mu \mathrm{m}$. Ext, external capsule of the hippocampus; Or, stratum oriens; Pyr, pyramidal layer.

form cortex (data not shown). TDP-43 tended to localize to subcellular regions with a high density of GFAP immunolabeling; however, pathological cytoplasmic TDP-43 immunoreactivity was detected less prominently in more distal astrocytic processes despite these processes being labeled for GFAP. Abnormal TDP-43 accumulation was not detected in neurons labeled with NeuN (data not shown).

\section{TDP-43 is insoluble and pathologically phosphorylated in} affected $\mathrm{AxD}$ mouse tissues

To confirm these IHC data, we conducted immunoblot analyses to determine the levels of total and phosphorylated TDP-43 in affected brain regions of $G f a p^{R 236 H /+}$ mice, including corpus callosum, hippocampus, and olfactory bulb. Total TDP-43 levels were not altered in the RIPA-soluble protein fraction in any re- 

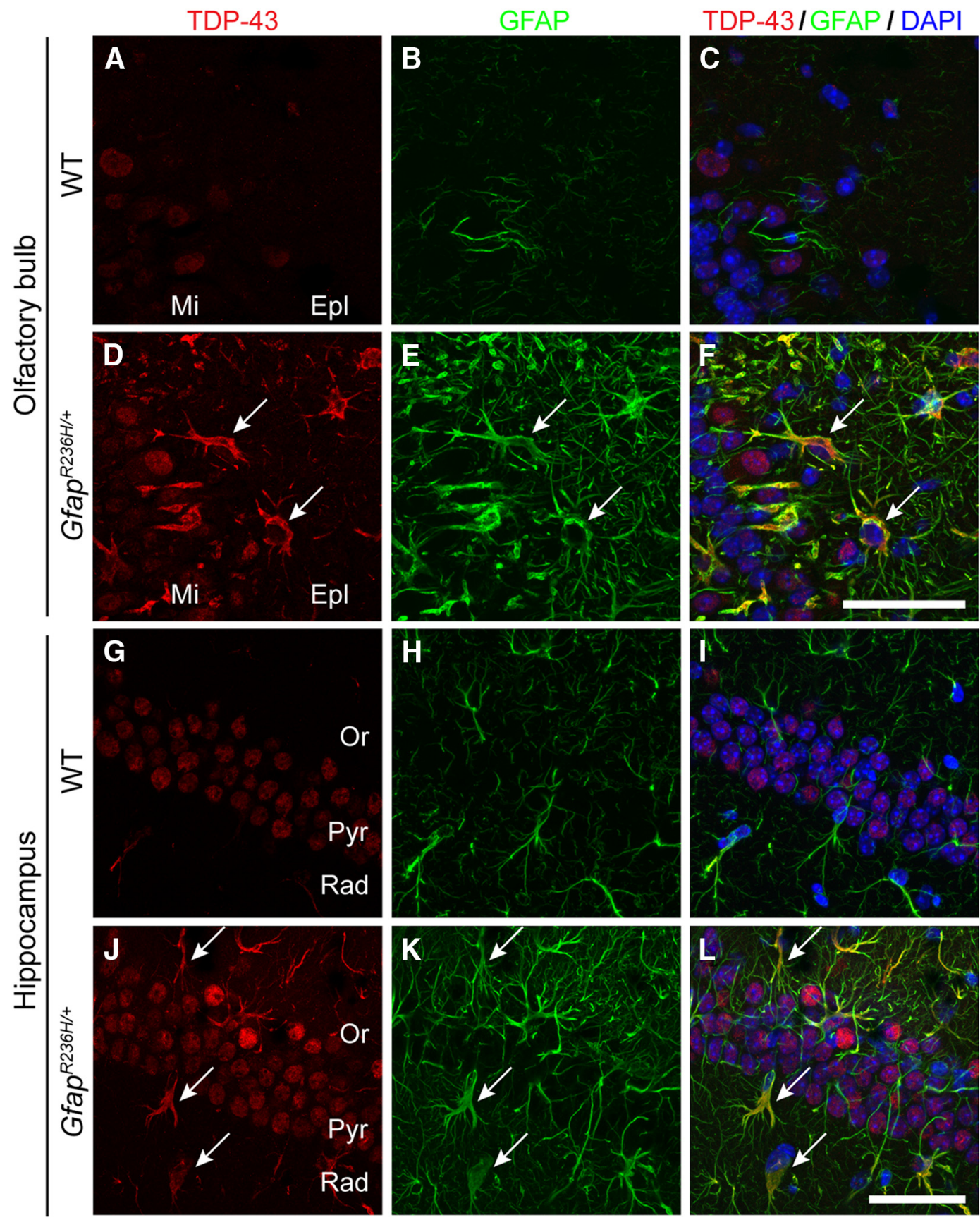

Figure 4. Mislocalized TDP-43 colocalizes with GFAP in Gfap ${ }^{R 236 H /+}$ mice. TDP-43 (red; antibody PTG 12892) and GFAP (green; antibody z0334) immunolabeling in coronal brain sections from 10-week-old mice (representative of $n=3$ mice per genotype). Nuclei are labeled with DAPI (blue). In WT mice, TDP-43 is primarily localized to nuclei in olfactory bulb (A) and the pyramidal layer (Pyr) of the hippocampus $(\boldsymbol{G})$, with very little colocalization with GFAP $(\boldsymbol{B}, \boldsymbol{C}, \boldsymbol{H}, \boldsymbol{I})$. In Gfap ${ }^{R 236 H /+}$ mice, TDP-43 is found in cell bodies and proximal processes in olfactory bulb (D) and hippocampus (J), and colocalizes with GFAP (arrows in $\boldsymbol{E}, \boldsymbol{F}, \boldsymbol{K}, \boldsymbol{L})$. Scale bars: $\boldsymbol{A}-\boldsymbol{F}, 50 \mu \mathrm{m} ; \boldsymbol{G}-\boldsymbol{L}, 50 \mu \mathrm{m}$. Epl, external plexiform layer; Mi, mitral cell layer; 0 r, stratum oriens; Rad, stratum radiatum.

gion of the $G f a p^{R 236 H /+}$ mice compared with littermate controls, despite $\sim 3$-fold increased levels of GFAP protein levels (Fig. $5 A-$ C). In contrast, although total TDP-43 levels in the RIPAinsoluble fraction were unchanged, a faint upper band was detected by the C1039 anti-TDP-43 antibody, which was absent in WT littermate controls. This immunoband was readily demonstrated to be pS409/410 TDP-43 using the anti-pS409/410 antibody (Fig. 5D-F). Moreover, in all affected regions analyzed in the $G f a p^{R 236 H /+}$ mice, we observed an increase in GFAP in the RIPA-insoluble fraction, and an increase in high molecular weight ubiquitinated proteins (Fig. $5 D-F$ ).
To investigate the specificity of the phospho-TDP-43 band, we performed enzymatic dephosphorylation of the RIPA-insoluble material. Treatment of Gfap ${ }^{R 236 H /+}$ mouse hippocampus with $\lambda$-phosphatase eliminated the pS409/410 TDP-4- immunoreactive species detected by immunoblotting, confirming the specificity of the antibody in the Gfap $\mathrm{R}^{236 \mathrm{H} / \mathrm{T}}$ mice (Fig. 6).

\section{Discussion}

Mislocalization of TDP-43 has previously been detected in a variety of neurodegenerative conditions (for review, see LagierTourenne et al., 2010; Lee et al., 2012), but it has been rarely 


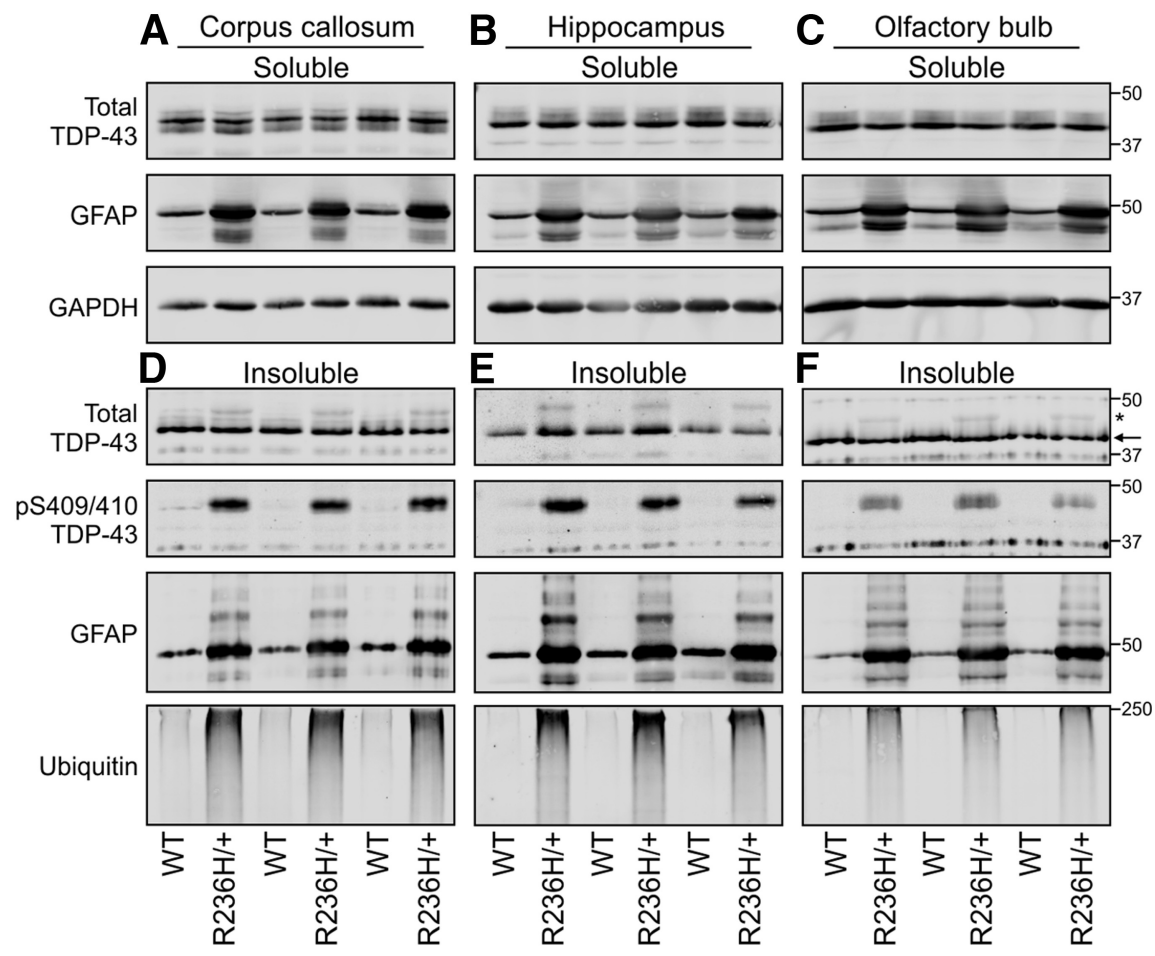

Figure 5. Levels of RIPA-soluble TDP-43 are unchanged but phosphorylated TDP-43 is detected in the RIPA-insoluble fraction in affected brain regions of $\mathrm{GFap}^{R 236 \mathrm{H} /+}$ mice. Immunoblotting for total TDP-43 (antibody (1039), GFAP, and GAPDH demonstrate no change in TDP-43 levels in Gfap ${ }^{R 236 H /+}$ mice compared with littermate controls despite upregulation of GFAP, in RIPA soluble fractions of corpus callosum (A), hippocampus (B), and olfactory bulb (C). Immunoblotting for total TDP-43 (antibody (1039) and pS409/410 TDP-43 (clone 1D3) demonstrate the presence of 43 kDa TDP-43 (arrow) as well as a higher TDP-43-immunoreactive band corresponding to pS409/410 TDP-43 (asterisk) in the RIPA-insoluble fractions of corpus callosum (D), hippocampus (E), and olfactory bulb $(\boldsymbol{F})$ from $\mathrm{Gfap}^{R 236 \mathrm{H} /+}$ mice, which is not detected in littermate controls. $G \mathrm{Gap}^{R 236 \mathrm{H} /+}$ mice also show increased levels of GFAP and high molecular weight ubiquitinated proteins in the RIPA-insoluble fractions. Each blot is representative of duplicate blots with samples from four 10-week-old GFAP ${ }^{R 236 H /+}$ mice and four WT littermate controls. Approximate molecular weight markers $(\mathrm{KDa})$ are shown on the right.

A

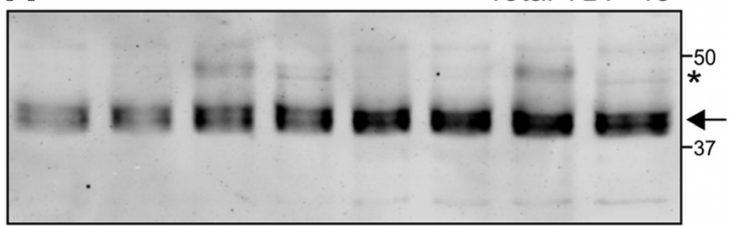

B

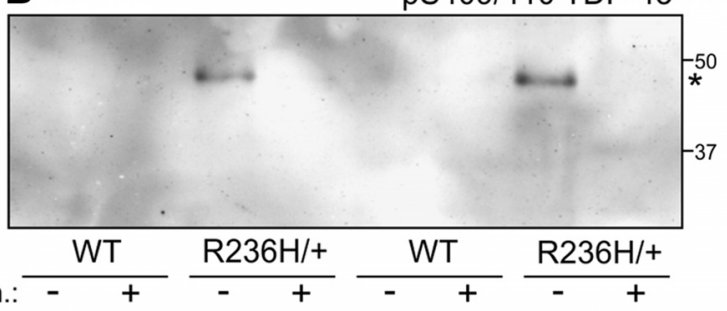

Figure 6. Treatment with $\lambda$-phosphatase eliminates p $\$ 409 / 410$ immunoreactivity in hippocampus of Gfap ${ }^{R 236 H /+}$ mice. SDS-insoluble fractions from two individual 10 -week-old WT littermate controls and two Gfap ${ }^{R 236 H /+}$ mice were dialyzed and treated with $\lambda$-phosphatase before SDS-PAGE and immunoblotting for (A) total TDP-43 (antibody (1039) and (B) pS409/ 410 TDP-43 (antibody 1D3). Approximate molecular weight markers ( $\mathrm{kDa}$ ) are shown on the right. Asterisk indicates phosphorylated TDP-43, and arrow indicates full-length TDP-43. Results are representative of two independent experiments analyzing tissues from four individual mice. studied in glia or glial degenerative diseases. Here we show that widespread TDP-43 pathology occurs in astrocytes of $\mathrm{AxD}$, a primarily astrocytic neurodegenerative disease. Human and mouse $\mathrm{AxD}$ CNS samples show that TDP-43 is mislocalized to the cytoplasm of astrocytes and becomes increasingly insoluble and pathologically phosphorylated coincident with an increase in high molecular weight ubiquitinated proteins. TDP-43 colocalizes with GFAP in RFs, and the amount of pathological TDP-43 increases with disease severity in both AxD mouse models and human $\mathrm{AxD}$ patients.

While the cytoplasmic localization, phosphorylation, and increased insolubility of TDP-43 in AxD are similar to what has been reported in other neurodegenerative diseases, such as ALS, FTLD-TDP, Alzheimer's disease, and Parkinson's disease (for review, see Lagier-Tourenne et al., 2010), TDP-43 pathology in AxD has several unique characteristics. First, insoluble C-terminal fragments of TDP-43 were absent or barely detectable in immunoblots of AxD tissue samples, in contrast to their prevalence in other neurodegenerative TDP-43 proteinopathies (Neumann et al., 2006). This supports evidence from other studies that the presence of C-terminal fragments of TDP-43 is not necessary for aberrant cytoplasmic localization, phosphorylation, or insolubility to occur (for review, see Lee et al., 2012), and could reflect differences in pathological TDP-43 processing in neurons compared with astrocytes. Second, unlike other neurodegenerative disorders characterized by TDP-43 inclusions, pathological TDP-43 aggregates are limited exclusively to astrocytes and RFs in $G f a p^{R 236 H /+}$ and $G F A P^{T s}$ mice as well as in $\mathrm{AxD}$ patients. Despite these differences, phosphorylated TDP-43 accumulation did occur along with an increase in ubiquitinated proteins, suggesting that normal protein clearance pathways are disrupted in $\mathrm{AxD}$ and that this could be linked mechanistically to TDP-43 pathology.

The formation of TDP-43 pathology in both Gfap ${ }^{R 236 H /+}$ and $G F A P^{T g}$ mice occurs in the absence of an increase in TDP-43 protein levels. This is in stark contrast to many previous transgenic mouse models of TDP-43 proteinopathy engineered to overexpress mutant, wild-type, or C-terminal TDP-43 proteins in which little or no TDP-43 pathology is detected in neurons or other cell types (for review, see Ling et al., 2013). This suggests that increasing levels of GFAP above a toxic threshold with subsequent formation of RF pathology induces accumulation of pathological TDP-43 in a manner that is not recapitulated simply by increasing TDP-43 expression. It should be noted that the astrocytic TDP-43 pathology in these mice differs from that seen in human AxD and other TDP-43 proteinopathies, since pathology in the mice was detected poorly by some C- and N-terminal TDP-43 antibodies despite detecting RFs in $\mathrm{AxD}$ patient samples and inclusions in FTLD using the conditions described here. This finding suggests differences in TDP-43 folding in the $G f a p^{R 236 H /+}$ and $G F A P^{T g}$ mice, which renders specific epitopes in TDP-43 
inaccessible to binding by anti-TDP-43 antibodies. How these differences in protein folding affect TDP-43 function and accumulation is an interesting area of future study.

TDP-43 pathology has previously been detected in astrocytic plaques and oligodendroglial inclusions in a small minority of cases of corticobasal degeneration (Uryu et al., 2008), in astrocytes of frontotemporal dementia with familial Lewy body disease (Lin et al., 2009), in neoplastic cells undergoing mitosis in low-grade gliomas and astrocytic RFs induced by prolonged gliosis in response to chronic brain lesions (Lee et al., 2008), and in astrocytes of one patient with Cockayne syndrome (Sakurai et al., 2013). WM TDP-43 pathology has also been detected in FTLDTDP, although this is likely predominantly oligodendrocytic (Neumann et al., 2007). However, this is the first report of a primarily astrocytic neurodegenerative disease showing TDP-43 pathology. Importantly, accumulation of TDP-43 in astrocytes in the $\mathrm{AxD}$ samples studied here is specifically related to the presence of RFs, and not reactive gliosis, since pathological TDP-43 distribution was not previously detected in a large series of brain biopsies of diverse CNS pathologies in which astrogliosis occurs, including primary and metastatic brain tumors, epilepsy and stroke (Lee et al., 2008).

The functional significance of astrocytic TDP-43 pathology, and whether this is involved in neurodegeneration in $\mathrm{AxD}$, remains to be determined. While TDP-43 pathology does not result in detectable astrocyte death in $G f a p^{R 236 H /+}$ mice, disruption of TDP-43 function by its mislocalization could cause several downstream-negative consequences. TDP-43 is involved in RNA splicing, regulation of transcription, mRNA stabilization, and miRNA processing and biogenesis, and thousands of RNAs are bound and potentially regulated by TDP-43 (Freibaum et al., 2010; for review, see Lagier-Tourenne et al., 2010; Polymenidou et al., 2011; Sephton et al., 2011; Tollervey et al., 2011; Xiao et al., 2011; Colombrita et al., 2012). If TDP-43 is sequestered in the cytoplasm and in RFs, regulation of these RNAs could be affected, leading to dysfunction of various cellular processes. For example, TDP-43 has been implicated in neural plasticity (Wang et al., 2008), cell cycle control (Ayala et al., 2008), mitochondrial function and trafficking (Shan et al., 2010; Xu et al., 2010), and autophagy (Caccamo et al., 2009; Urushitani et al., 2010; Bose et al., 2011). Indeed, given that loss of normal nuclear TDP-43 in neurons is postulated as a key mechanism of dysfunction in ALS and FTLD (Igaz et al., 2011), it is likely that the recruitment of TDP-43 to astrocytic RFs leads to similar disruption of normal nuclear TDP-43 functions with detrimental downstream effects in AxD. Since transactivation of the Gfap promoter is an early event in pathogenesis in the $\mathrm{AxD}$ mouse models (Jany et al., 2013), and alternative splicing leads to multiple isoforms of both mouse and human GFAP with varying subcellular distribution and functional roles (Roelofs et al., 2005; Middeldorp and Hol, 2011; Thomsen et al., 2013), it is possible that alterations in TDP-43 targets, such as transcription factors or miRNAs, could lead to increases in GFAP synthesis with subsequent formation of pathology. Furthermore, postnatal deletion of the key miRNA endoribonuclease Dicer specifically from astrocytes leads to agedependent neurological dysfunction, including ataxia and seizures, resulting in early death (Tao et al., 2011). These findings indicate that perturbation of miRNA biogenesis in astrocytes, as may result from TDP-43 mislocalization in $\mathrm{AxD}$, can also lead to non-cell autonomous neurological disorders.

Another additional mechanism potentially linked to TDP-43 pathology in $\mathrm{AxD}$ is the activation of cellular stress pathways. Numerous cellular stressors, including nutrient deprivation, ox- idative stress, and endoplasmic reticulum stress, have been shown to cause cytoplasmic TDP-43 accumulation and association with stress granules in a variety of cell culture models (for review, see Dewey et al., 2012). JNK activation has also been shown in cell culture to mediate TDP-43 redistribution to the cytoplasm in response to oxidative stress (Meyerowitz et al., 2011). Given that in cell culture and Drosophila models of AxD, oxidative stress-associated JNK pathway activation occurs in a time-dependent manner (Tang et al., 2006; Wang et al., 2011), one possibility is that astrocytic stress caused by GFAP accumulation leads to cytoplasmic TDP-43 redistribution, and that accumulation of TDP-43 within RFs occurs secondarily. The additional association of TDP-43 with RFs may also reflect its interaction with the ubiquitin-binding protein p62 (Brady et al., 2011), which similarly accumulates in RFs (Zatloukal et al., 2002).

TDP-43 is detected at low levels outside the nucleus and shuttles between the nucleus and cytoplasm even under normal conditions (Ayala et al., 2008; Winton et al., 2008; Fallini et al., 2012). Using electron microscopy, GFAP intermediate filaments appear to be localized near pores in the nuclear envelope, and are associated with some mRNAs outside the nucleus (Erickson et al., 1992). Mutant GFAP or GFAP overexpression may disrupt nuclear transport of TDP-43, which could further lead to accumulation of TDP-43 in the cytoplasm in AxD. Furthermore, alterations in protein degradative pathways in disease also likely play a role in the accumulation of pathological GFAP and TDP43. Although autophagy is increased in $\mathrm{AxD}$ and may contribute to the clearance of GFAP, proteasomal function is impaired, and so the net effect on GFAP degradation is unclear (Tang et al., 2006, 2008). However, TDP-43 is degraded via both the ubiquitin-proteasome (UPS) and autophagy systems (Wang et al., 2010), and inhibition of the UPS increases phosphorylated TDP-43 aggregates in cell culture (Winton et al., 2008). These findings suggest that any perturbation of degradation pathways in AxD could have concomitant effects on both GFAP and TDP43 , leading to the accumulation of both pathological proteins.

In conclusion, we extend the scope of neurodegenerative TDP-43 proteinopathies by demonstrating widespread astrocytic TDP-43 pathology in $\mathrm{AxD}$, with a particular burden of phosphorylated TDP-43 in the youngest, most severely affected patients. In addition, the Gfap ${ }^{R 236 H /+}$ and GFAP $P^{T g}$ mouse models also displayed considerable astrocytic TDP-43 pathology and may prove to be useful tools for studies of the mechanisms underlying TDP-43 mislocalization, phosphorylation, and accumulation, with implications for $\mathrm{AxD}$ as well as other neurodegenerative diseases.

\section{References}

Ayala YM, Misteli T, Baralle FE (2008) TDP-43 regulates retinoblastoma protein phosphorylation through the repression of cyclin-dependent kinase 6 expression. Proc Natl Acad Sci USA 105:3785-3789. CrossRef Medline

Bose JK, Huang CC, Shen CK (2011) Regulation of autophagy by neuropathological protein TDP-43. J Biol Chem 286:44441-44448. CrossRef Medline

Brady OA, Meng P, Zheng Y, Mao Y, Hu F (2011) Regulation of TDP-43 aggregation by phosphorylation and p62/SQSTM1. J Neurochem 116: 248-259. CrossRef Medline

Brenner M, Johnson AB, Boespflug-Tanguy O, Rodriguez D, Goldman JE, Messing A (2001) Mutations in GFAP, encoding glial fibrillary acidic protein, are associated with Alexander disease. Nat Genet 27:117-120. CrossRef Medline

Caccamo A, Majumder S, Deng JJ, Bai Y, Thornton FB, Oddo S (2009) Rapamycin rescues TDP-43 mislocalization and the associated low mo- 
lecular mass neurofilament instability. J Biol Chem 284:27416-27424. CrossRef Medline

Colombrita C, Onesto E, Megiorni F, Pizzuti A, Baralle FE, Buratti E, Silani V, Ratti A (2012) TDP-43 and FUS RNA-binding proteins bind distinct sets of cytoplasmic messenger RNAs and differently regulate their posttranscriptional fate in motoneuron-like cells. J Biol Chem 287:1563515647. CrossRef Medline

Dewey CM, Cenik B, Sephton CF, Johnson BA, Herz J, Yu G (2012) TDP-43 aggregation in neurodegeneration: are stress granules the key? Brain Res 1462:16-25. CrossRef Medline

Erickson PA, Feinstein SC, Lewis GP, Fisher SK (1992) Glial fibrillary acidic protein and its mRNA: ultrastructural detection and determination of changes after CNS injury. J Struct Biol 108:148-161. CrossRef Medline

Fallini C, Bassell GJ, Rossoll W (2012) The ALS disease protein TDP-43 is actively transported in motor neuron axons and regulates axon outgrowth. Hum Mol Genet 21:3703-3718. CrossRef Medline

Freibaum BD, Chitta RK, High AA, Taylor JP (2010) Global analysis of TDP-43 interacting proteins reveals strong association with RNA splicing and translation machinery. J Proteome Res 9:1104-1120. CrossRef Medline

Hagemann TL, Connor JX, Messing A (2006) Alexander disease-associated glial fibrillary acidic protein mutations in mice induce Rosenthal fiber formation and a white matter stress response. J Neurosci 26:11162-11173. CrossRef Medline

Hagemann TL, Paylor R, Messing A (2013) Deficits in adult neurogenesis, contextual fear conditioning, and spatial learning in a Gfap mutant mouse model of alexander disease. J Neurosci 33:18698-18706. CrossRef Medline

Igaz LM, Kwong LK, Xu Y, Truax AC, Uryu K, Neumann M, Clark CM, Elman LB, Miller BL, Grossman M, McCluskey LF, Trojanowski JQ, Lee VM (2008) Enrichment of C-terminal fragments in TAR DNA-binding protein-43 cytoplasmic inclusions in brain but not in spinal cord of frontotemporal lobar degeneration and amyotrophic lateral sclerosis. Am J Pathol 173:182-194. CrossRef Medline

Igaz LM, Kwong LK, Lee EB, Chen-Plotkin A, Swanson E, Unger T, Malunda J, Xu Y, Winton MJ, Trojanowski JQ, Lee VM (2011) Dysregulation of the ALS-associated gene TDP-43 leads to neuronal death and degeneration in mice. J Clin Invest 121:726-738. CrossRef Medline

Jany PL, Hagemann TL, Messing A (2013) GFAP expression as an indicator of disease severity in mouse models of Alexander disease. ASN Neuro 5:e00109. Medline DOI not found.

Lagier-Tourenne C, Polymenidou M, Cleveland DW (2010) TDP-43 and FUS/TLS: emerging roles in RNA processing and neurodegeneration. Hum Mol Genet 19:R46-R64. CrossRef Medline

Lee EB, Lee VM, Trojanowski JQ, Neumann M (2008) TDP-43 immunoreactivity in anoxic, ischemic and neoplastic lesions of the central nervous system. Acta Neuropathol 115:305-311. CrossRef Medline

Lee EB, Lee VM, Trojanowski JQ (2012) Gains or losses: molecular mechanisms of TDP43-mediated neurodegeneration. Nat Rev Neurosci 13:3850. CrossRef Medline

Lee VM, Page CD, Wu HL, Schlaepfer WW (1984) Monoclonal antibodies to gel-excised glial filament protein and their reactivities with other intermediate filament proteins. J Neurochem 42:25-32. CrossRef Medline

Lin WL, Castanedes-Casey M, Dickson DW (2009) Transactivation response DNA-binding protein 43 microvasculopathy in frontotemporal degeneration and familial Lewy body disease. J Neuropathol Exp Neurol 68:1167-1176. CrossRef Medline

Ling SC, Polymenidou M, Cleveland DW (2013) Converging mechanisms in ALS and FTD: disrupted RNA and protein homeostasis. Neuron 79: 416-438. CrossRef Medline

Messing A, Head MW, Galles K, Galbreath EJ, Goldman JE, Brenner M (1998) Fatal encephalopathy with astrocyte inclusions in GFAP transgenic mice. Am J Pathol 152:391-398. Medline DOI not found.

Messing A, Brenner M, Feany MB, Nedergaard M, Goldman JE (2012) Alexander disease. J Neurosci 32:5017-5023. CrossRef Medline

Meyerowitz J, Parker SJ, Vella LJ, Ng DCh, Price KA, Liddell JR, Caragounis A, Li QX, Masters CL, Nonaka T, Hasegawa M, Bogoyevitch MA, Kanninen KM, Crouch PJ, White AR (2011) C-Jun N-terminal kinase controls TDP-43 accumulation in stress granules induced by oxidative stress. Mol Neurodegener 6:57. CrossRef Medline

Middeldorp J, Hol EM (2011) GFAP in health and disease. Prog Neurobiol 93:421-443. CrossRef Medline
Nakashima-Yasuda H, Uryu K, Robinson J, Xie SX, Hurtig H, Duda JE, Arnold SE, Siderowf A, Grossman M, Leverenz JB, Woltjer R, Lopez OL, Hamilton R, Tsuang DW, Galasko D, Masliah E, Kaye J, Clark CM, Montine TJ, Lee VM, et al. (2007) Co-morbidity of TDP-43 proteinopathy in Lewy body related diseases. Acta Neuropathol 114:221-229. CrossRef Medline

Neumann M, Sampathu DM, Kwong LK, Truax AC, Micsenyi MC, Chou TT, Bruce J, Schuck T, Grossman M, Clark CM, McCluskey LF, Miller BL, Masliah E, Mackenzie IR, Feldman H, Feiden W, Kretzschmar HA, Trojanowski JQ, Lee VM (2006) Ubiquitinated TDP-43 in frontotemporal lobar degeneration and amyotrophic lateral sclerosis. Science 314:130133. CrossRef Medline

Neumann M, Kwong LK, Truax AC, Vanmassenhove B, Kretzschmar HA, Van Deerlin VM, Clark CM, Grossman M, Miller BL, Trojanowski JQ, Lee VM (2007) TDP-43-positive white matter pathology in frontotemporal lobar degeneration with ubiquitin-positive inclusions. J Neuropathol Exp Neurol 66:177-183. CrossRef Medline

Neumann M, Kwong LK, Lee EB, Kremmer E, Flatley A, Xu Y, Forman MS, Troost D, Kretzschmar HA, Trojanowski JQ, Lee VM (2009) Phosphorylation of S409/410 of TDP-43 is a consistent feature in all sporadic and familial forms of TDP-43 proteinopathies. Acta Neuropathol 117:137149. CrossRef Medline

Polymenidou M, Lagier-Tourenne C, Hutt KR, Huelga SC, Moran J, Liang TY, Ling SC, Sun E, Wancewicz E, Mazur C, Kordasiewicz H, Sedaghat Y, Donohue JP, Shiue L, Bennett CF, Yeo GW, Cleveland DW (2011) Long pre-mRNA depletion and RNA missplicing contribute to neuronal vulnerability from loss of TDP-43. Nat Neurosci 14:459-468. CrossRef Medline

Prust M, Wang J, Morizono H, Messing A, Brenner M, Gordon E, Hartka T, Sokohl A, Schiffmann R, Gordish-Dressman H, Albin R, Amartino H, Brockman K, Dinopoulos A, Dotti MT, Fain D, Fernandez R, Ferreira J, Fleming J, Gill D, et al. (2011) GFAP mutations, age at onset, and clinical subtypes in Alexander disease. Neurology 77:1287-1294. CrossRef Medline

Roelofs RF, Fischer DF, Houtman SH, Sluijs JA, Van Haren W, Van Leeuwen FW, Hol EM (2005) Adult human subventricular, subgranular, and subpial zones contain astrocytes with a specialized intermediate filament cytoskeleton. Glia 52:289-300. CrossRef Medline

Sakurai A, Makioka K, Fukuda T, Takatama M, Okamoto K (2013) Accumulation of phosphorylated TDP-43 in the CNS of a patient with Cockayne syndrome. Neuropathology 33:673-677. CrossRef Medline

Schwab C, Arai T, Hasegawa M, Yu S, McGeer PL (2008) Colocalization of transactivation-responsive DNA-binding protein 43 and huntingtin in inclusions of Huntington disease. J Neuropathol Exp Neurol 67:1159_ 1165. CrossRef Medline

Sephton CF, Cenik C, Kucukural A, Dammer EB, Cenik B, Han Y, Dewey CM, Roth FP, Herz J, Peng J, Moore MJ, Yu G (2011) Identification of neuronal RNA targets of TDP-43-containing ribonucleoprotein complexes. J Biol Chem 286:1204-1215. CrossRef Medline

Shan X, Chiang PM, Price DL, Wong PC (2010) Altered distributions of Gemini of coiled bodies and mitochondria in motor neurons of TDP-43 transgenic mice. Proc Natl Acad Sci USA 107:16325-16330. CrossRef Medline

Tang G, Xu Z, Goldman JE (2006) Synergistic effects of the SAPK/JNK and the proteasome pathway on glial fibrillary acidic protein (GFAP) accumulation in Alexander disease. J Biol Chem 281:38634-38643. CrossRef Medline

Tang G, Yue Z, Talloczy Z, Hagemann T, Cho W, Messing A, Sulzer DL, Goldman JE (2008) Autophagy induced by Alexander disease-mutant GFAP accumulation is regulated by p38/MAPK and mTOR signaling pathways. Hum Mol Genet 17:1540-1555. CrossRef Medline

Tao J, Wu H, Lin Q, Wei W, Lu XH, Cantle JP, Ao Y, Olsen RW, Yang XW, Mody I, Sofroniew MV, Sun YE (2011) Deletion of astroglial Dicer causes non-cell-autonomous neuronal dysfunction and degeneration. J Neurosci 31:8306-8319. CrossRef Medline

Thomsen R, Daugaard TF, Holm IE, Nielsen AL (2013) Alternative mRNA splicing from the glial fibrillary acidic protein (GFAP) gene generates isoforms with distinct subcellular mRNA localization patterns in astrocytes. PLoS One 8:e72110. CrossRef Medline

Tollervey JR, Curk T, Rogelj B, Briese M, Cereda M, Kayikci M, König J, Hortobágyi T, Nishimura AL, Zupunski V, Patani R, Chandran S, Rot G, Zupan B, Shaw CE, Ule J (2011) Characterizing the RNA targets and 
position-dependent splicing regulation by TDP-43. Nat Neurosci 14:452458. CrossRef Medline

Urushitani M, Sato T, Bamba H, Hisa Y, Tooyama I (2010) Synergistic effect between proteasome and autophagosome in the clearance of polyubiquitinated TDP-43. J Neurosci Res 88:784-797. CrossRef Medline

Uryu K, Nakashima-Yasuda H, Forman MS, Kwong LK, Clark CM, Grossman M, Miller BL, Kretzschmar HA, Lee VM, Trojanowski JQ, Neumann M (2008) Concomitant TAR-DNA-binding protein 43 pathology is present in Alzheimer disease and corticobasal degeneration but not in other tauopathies. J Neuropathol Exp Neurol 67:555-564. CrossRef Medline

Wang IF, Wu LS, Chang HY, Shen CK (2008) TDP-43, the signature protein of FTLD-U, is a neuronal activity-responsive factor. J Neurochem 105: 797-806. CrossRef Medline

Wang L, Colodner KJ, Feany MB (2011) Protein misfolding and oxidative stress promote glial-mediated neurodegeneration in an Alexander disease model. J Neurosci 31:2868-2877. CrossRef Medline

Wang X, Fan H, Ying Z, Li B, Wang H, Wang G (2010) Degradation of TDP-43 and its pathogenic form by autophagy and the ubiquitinproteasome system. Neurosci Lett 469:112-116. CrossRef Medline

Wilson RS, Yu L, Trojanowski JQ, Chen EY, Boyle PA, Bennett DA, Schneider
JA (2013) TDP-43 pathology, cognitive decline, and dementia in old age. JAMA Neurol 70:1418-1424. CrossRef Medline

Winton MJ, Igaz LM, Wong MM, Kwong LK, Trojanowski JQ, Lee VM (2008) Disturbance of nuclear and cytoplasmic TAR DNA-binding protein (TDP-43) induces disease-like redistribution, sequestration, and aggregate formation. J Biol Chem 283:13302-13309. CrossRef Medline

Xiao S, Sanelli T, Dib S, Sheps D, Findlater J, Bilbao J, Keith J, Zinman L, Rogaeva E, Robertson J (2011) RNA targets of TDP-43 identified by UV-CLIP are deregulated in ALS. Mol Cell Neurosci 47:167-180. CrossRef Medline

Xu YF, Gendron TF, Zhang YJ, Lin WL, D'Alton S, Sheng H, Casey MC, Tong J, Knight J, Yu X, Rademakers R, Boylan K, Hutton M, McGowan E, Dickson DW, Lewis J, Petrucelli L (2010) Wild-type human TDP-43 expression causes TDP-43 phosphorylation, mitochondrial aggregation, motor deficits, and early mortality in transgenic mice. J Neurosci 30 : 10851-10859. CrossRef Medline

Zatloukal K, Stumptner C, Fuchsbichler A, Heid H, Schnoelzer M, Kenner L, Kleinert R, Prinz M, Aguzzi A, Denk H (2002) p62 Is a common component of cytoplasmic inclusions in protein aggregation diseases. Am J Pathol 160:255-263. CrossRef Medline 